\title{
Transcriptional regulation of glucose-6-phosphatase catalytic subunit promoter by insulin and glucose in the carnivorous fish, Sparus aurata
}

\author{
M C Salgado, I Metón, M Egea and I V Baanante \\ Departament de Bioquímica i Biologia Molecular, Facultat de Farmácia, Universitat de Barcelona, Diagonal 643, 08028 Barcelona, Spain
}

(Requests for offprints should be addressed to I V Baanante; Email: baanantevazquez@ub.edu)

\begin{abstract}
Increase in glucose-6-phosphatase catalytic subunit (G6Pase, G6pc) transcription enhances hepatic glucose production in non-insulin-dependent diabetes mellitus (NIDDM). The fact that carnivorous fish is an alternative model to study NIDDM led us to clone and characterise the first G6pc promoter region reported for fish and non-mammalian animals. The $5^{\prime}$-flanking region of $G 6 p c$ from gilthead sea bream (Sparus aurata) was isolated by chromosome walking. With SMART RACE-PCR, the transcription start site was located 106 base pairs (bp) upstream of the translational start. Transfection analysis in HepG2 cells located a functional promoter in the $850 \mathrm{bp} 5^{\prime}$-flanking isolated fragment (positions -770 to +80 relative to the transcription start). Sequential 5 '-deletion analysis of the promoter fragment revealed that a core functional promoter for basal transcription is comprised within the $190 \mathrm{bp}$ upstream of the transcription start site. In vivo, glucose and insulin reduced G6Pase mRNA levels in the fish liver. Transfection experiments in HepG2 cells showed that insulin repressed S. aurata G6pc under high-glucose conditions. Synergistic activation of piscine G6pc promoter was induced by cotransfection with expression plasmids for hepatocyte nuclear factor- $4 \alpha$ (HNF-4 $\alpha$ ) and peroxisome proliferatoractivated receptor- $\gamma$ coactivator-1 (PGC-1 $\alpha$ ). No direct relationship was found between PGC-1 $\alpha$ coactivation of HNF- $4 \alpha$ transactivation and the repressive effect of insulin. Interestingly, insulin hardly affected G6pc promoter activity in the absence of glucose, suggesting that a reduced capacity of insulin-dependent repression of piscine G6pc may lead to insulin resistance in carnivorous fish.
\end{abstract}

Journal of Molecular Endocrinology (2004) 33, 783-795

\section{Introduction}

In mammals, liver glucose-6-phosphatase (EC $3 \cdot 1 \cdot 3 \cdot 9$, G6Pase, G6pc) plays a key role in blood glucose homeostasis by catalysing the dephosphorylation of glucose-6-phosphate (G-6P) to glucose, the terminal reaction of gluconeogenesis and glycogenolysis. According to the substrate-transport model, G6Pase is a multicomponent complex located in the endoplasmic reticulum. Hydrolysis of G-6P involves the coupled functions of different membrane-spanning translocases that mediate penetration of G-6P and efflux of inorganic phosphate $(\mathrm{Pi})$ and glucose (Van de Werve et al. 2000, Clottes et al. 2002, Foster \& Nordlie 2002, Van Schaftingen \& Gerin 2002). Expression of the catalytic subunit of G6Pase is restricted to liver, kidney, small intestine and brain (Gautier-Stein et al. 2003, Guionie et al. 2003). Hepatic G6pc gene expression is hormonally and nutritionally regulated. G6pc expression is stimulated by glucose, glucocorticoids, cAMP, fatty acids, leptin and $\beta_{3}$-adrenergic receptor agonists, whereas it is inhibited by tumour necrosis factor $\alpha$, interleukin- 6 and insulin (Streeper et al. 2000). Studies in vivo and in vitro indicate that $G 6 p c$ expression in rats is stimulated by glucose and xylitol, irrespective of insulin, through different signalling pathways (Massillon et al. 1996, 1998, Massillon 2001, Pagliassotti et al. 2003). Insulin inhibits gluconeogenesis by suppressing the expression of key enzymes, such as G6Pase. In HepG2 cells, repression of $G 6 p c$ transcription by insulin requires two regions in the proximal promoter, designated 
$\mathrm{A}$ and B. Hepatocyte nuclear factor (HNF)-1 binds to region A, and enhances the effect of insulin (Streeper et al. 1998). Recently, insulin was postulated to downregulate $G 6 p c$ expression by inhibiting the binding of a transcriptional activator, the forkhead transcription factor Foxol (also known as FKHR), to insulin response sequence (IRS) motifs located in region B (Vander Kooi et al. 2003). The dual-specificity protein kinase DYRK1A synergistically potentiates transactivation of $G 6 p c$ by Foxol (Von Groote-Bidlingmaier et al. 2003). Short-chain fatty acids induce G6pc transcription via recruitment of HNF- $4 \alpha$ to the promoter (Massillon et al. 2003). Recent studies have shown that transcriptional activation of the G6pc promoter by HNF-4 $\alpha$ and Foxol involves the coactivator protein peroxisome proliferatoractivated receptor- $\gamma$ coactivator-1 (PGG-1 $\alpha)$ (Herzig et al. 2001, Yoon et al. 2001, Boustead et al. 2003, Puigserver et al. 2003, Rhee et al. 2003). CRE-binding protein (CREB) mediates activation of $G 6 p c$ transcription through binding to a cAMP response element (CRE), which contributes to the regulation of the gene transcription by both cAMP and glucocorticoids (Schmoll et al. 1999). Additionally, binding of HNF-3 $\gamma$ and Sp family proteins is essential for the basal activity of $G 6 p c$ promoter (Lin et al. 1997, Wasner et al. 2001).

In carnivorous fish, glucose intolerance and limited use of dietary carbohydrates have been reported. Compared with mammals, these animals show prolonged hyperglycaemia after a glucose load and when fed high-carbohydrate diets (Christiansen \& Klungsøyr 1987, Cowey \& Walton 1989, Baanante et al. 1991, Wilson 1994, Moon 2001, Metón et al. 2003). This metabolic profile mimics non-insulin-dependent diabetes mellitus (NIDDM) in humans, and carnivorous fish are thus considered as an alternative model in which to study NIDDM (Wilson 1994, Moon 2001). In patients with NIDDM, hepatic gluconeogenesis is increased; the inability of insulin to control enzymes such as G6Pase contributes to hyperglycaemia (Streeper et al. 1997, Clore et al. 2000). Consistent with a model whereby a reduction of G6Pase activity affects glucose homeostasis, silencing of hepatic $G 6 p c$ reduces postprandial serum glucose levels in mice (Huang et al. 2004). In the present study, to understand regulation of $G 6 p c$ transcription in the carnivorous fish glucose-intolerant model, we have cloned the first $G 6 p c$ catalytic subunit promoter reported for fish and non-mammalian animals. In addition, we characterised regulation of the proximal promoter region activity of piscine $G 6 p c$ by glucose and insulin, and transactivation by HNF- $4 \alpha$ and the coactivator PGG- $1 \alpha$.

\section{Materials and methods}

\section{Animal treatments}

Gilthead sea bream (Sparus aurata) obtained from Tinamenor (Cantabria, Spain) were maintained, at $20^{\circ} \mathrm{C}$, in 260-l aquaria supplied with running seawater in a closed system with an active pump filter and UV lamps. The photoperiod was a $12 \mathrm{~h} / 12 \mathrm{~h}$ dark/light cycle. Fish were fed daily $(1000 \mathrm{~h})$ at $1 \%$ body weight with a diet containing $46 \%$ protein, $9.3 \%$ carbohydrates, $22 \%$ lipids, $10 \cdot 6 \%$ ash and $12 \cdot 1 \%$ moisture, and $21 \cdot 1 \mathrm{~kJ} / \mathrm{g}$ gross energy. To study regulation of G6pc expression by insulin and glucose in vivo, we divided the animals into four groups of six fish each. At $24 \mathrm{~h}$ after the last meal (at $10 \mathrm{~h}$ ), three different groups received an intraperitoneal injection of glucose $(2 \mathrm{~g} / \mathrm{kg}$ fish), bovine insulin (10 units $/ \mathrm{kg}$ fish) (Sigma) or glucose (2 $\mathrm{g} / \mathrm{kg}$ fish) plus insulin (10 units/kg fish). The other group was injected with vehicle (saline). At $6 \mathrm{~h}$ after treatment, fish were killed by cervical section. Blood was collected, and liver samples were dissected out, immediately frozen in liquid $\mathrm{N}_{2}$ and kept at $-80{ }^{\circ} \mathrm{C}$ until use. To avoid stress, fish were anaesthetised with MS-222 (1:12 500) before handling. The experimental procedures met the guidelines of the animal use committee of the University of Barcelona.

\section{Cloning of the 5'-flanking region of G6pc from S. aurata by chromosome walking}

The 5'-flanking region of $G 6 p c$ was isolated by PCR with the Universal GenomeWalker Kit (Clontech). Briefly, four libraries were obtained by blunt-end digestion of $S$. aurata genomic DNA with DraI, EcoRV, PvuII and StuI. Each batch of digested genomic DNA was ligated to the GenomeWalker adaptor provided in the kit. Primary PCR was performed on each library with the gene-specific primer MCGP01 (5'-TGGACGCGCGAGCTGT GCAGAAGATC- $3^{\prime}$ ) and the AP-1 primer provided in the kit. Seven initial cycles were carried out, with 25-s denaturation at $94{ }^{\circ} \mathrm{C}$, and 3-min 
annealing and DNA synthesis at $72{ }^{\circ} \mathrm{C}$, followed by 32 cycles in which the annealing and DNA synthesis temperature was $67^{\circ} \mathrm{C}$, and a final extension step of 7 min at $67^{\circ} \mathrm{C}$. Nested PGR was performed on the primary PCR product with the gene-specific primer MCGP02 (5'-GATGGCTCAGCCTCTGCGTG AGGATG-3') and the AP2 primer from the kit. The PCR reaction mixture was incubated for 2 min at $94^{\circ} \mathrm{C}$ and subjected to five cycles of denaturation at $94{ }^{\circ} \mathrm{C}$ for $25 \mathrm{~s}$, annealing at $68{ }^{\circ} \mathrm{C}$ for $30 \mathrm{~s}$ and DNA synthesis at $72{ }^{\circ} \mathrm{C}$ for $90 \mathrm{~s}$, followed by 20 cycles in which the annealing temperature was $65^{\circ} \mathrm{C}$, and a final extension step of $5 \mathrm{~min}$ at $72{ }^{\circ} \mathrm{C}$. The longer amplification product, a single $850 \mathrm{bp}$ band, was obtained from the DraI library and ligated into pGEM T Easy plasmid (Promega) to generate pGEM-P850. Two independent clones were fully sequenced on both strands, according to the ABI Prism BigDye Terminator Cycle Sequencing Ready Reaction kit instructions (Applied Biosystems, Foster City, CA, USA).

\section{Characterisation of the transcription start site}

The 5' end of the hepatic S. aurata G6Pase cDNA was determined by the SMART RACE cDNA Amplification Kit (Clontech). This generates fulllength cDNAs in reverse transcription reactions (Zhu et al. 2001). In brief, $1 \mu \mathrm{g}$ poly $\mathrm{A}^{+}$RNA obtained from liver of $S$. aurata was converted into cDNA with PowerScript RT (Ciontech, Palo Alto, CA, USA) at $42{ }^{\circ} \mathrm{C}$ for 1.5 h. $5^{\prime}$-RACE ready cDNA was obtained with the $5^{\prime}$-CDS primer, for firststrand synthesis, and the SMART II A oligonucleotides from the kit. After the end of the mRNA template is reached, the terminal transferase activity of PowerScript RT adds several dC residues that allow annealing of the SMART II A oligonucleotide, which serves as an extended template for RT. A touchdown PGR was conducted with the Universal Primer Mix A from the kit and MCGP01 oligonucleotides. Five initial cycles were carried out, with 30-s denaturation at $94^{\circ} \mathrm{C}$ and 1-min annealing and extension at $72{ }^{\circ} \mathrm{C}$, followed by five cycles with 30-s denaturation at $94{ }^{\circ} \mathrm{C}, 30$-s annealing at $70{ }^{\circ} \mathrm{C}$ and 1 -min extension at $72{ }^{\circ} \mathrm{C}$, and 20 cycles with 30 -s denaturation at $94{ }^{\circ} \mathrm{C}, 30$-s annealing at $68{ }^{\circ} \mathrm{C}$ and 1 -min extension at $72{ }^{\circ} \mathrm{C}$. The single $187 \mathrm{bp}$ band generated was purified and ligated into pGEM T Easy plasmid (Promega). Identical nucleotide sequence corresponding to the 5' end of G6Pase
cDNA was obtained by sequence analysis of two independent clones.

\section{Construction of reporter gene plasmids}

The $S$. aurata $G 6 p c$-luciferase reporter fusion construct harbouring promoter sequences located between positions -770 and +80 relative to the transcription start site (pGP770) was generated by PGR. To this end, a forward MCGP05 primer (5'-GCGCTAGCGACGGCGCGGGCTGGTAAA $-3^{\prime}$ ), extending from positions -770 to -751 , and containing a 5 -anchor sequence with an NheI site (underlined), a reverse MCGP06 oligonucleotide (5'-GCAAGCTTGATGGCTCAGCGTCTGCGT G-3') between positions +87 and +107 with a 5 '-anchor sequence containing a HindIII site (underlined), and pGEM-P850 as a template were used. The PCR product was cloned into the NheI/HindIII digested pGL3-Basic promoterless luciferase reporter plasmid (Promega). The reporter constructs designated as pGP629, pGP190 and pGP51 were produced by self-ligation of filled-in ends of pGP770 after digestion with EcoRV/HindIII, SmaI/HindIII and XhoI/ HindIII respectively. All constructs were verified by sequencing with the ABI Prism BigDye Terminator Cycle Sequencing Ready Reaction kit (Applied Biosystems, Foster City, CA, USA).

\section{Cell transfection and luciferase assay}

The human hepatoma derived cell line HepG2 (ATCG HB 8065) was cultured in Dulbecco's modified Eagle's medium (D-MEM), supplemented with $10 \%$ fetal bovine serum, $100 \mathrm{IU} / \mathrm{ml}$ penicillin, $100 \mu \mathrm{g} / \mathrm{ml}$ streptomycin and $2 \mathrm{mM}$ glutamine. The cells were grown at $37^{\circ} \mathrm{C}$ in $5 \% \mathrm{CO}_{2}$. The calcium phosphate coprecipitation method was used for transient transfection of HepG2 at 45-50\% confluence in six-well plates (Graham \& Van der Eb 1973). Cells were transfected with $4 \mu \mathrm{g}$ reporter construct, and when necessary, with $800 \mathrm{ng}$ expression vector encoding human insulin receptor $\mathrm{B}$, or $400 \mathrm{ng}$ expression vectors encoding HNF-4 $\alpha$ or PGC-1 $\alpha$. To correct for variations in transfection efficiency, $500 \mathrm{ng}$ CMV- $\beta$ (lacZ) were included in each transfection. To ensure equal DNA amounts, empty plasmids were added in each transfection. At $4 \mathrm{~h}$ after addition of the precipitate, cells were shocked in $10 \%$ dimethylsulphoxide in 
serum-free medium for $2 \mathrm{~min}$. Fresh medium or serum-free medium (supplemented with glucose or recombinant human insulin (Sigma)) was added, and the cells were harvested $16 \mathrm{~h}$ later, washed in PBS and incubated for $15 \mathrm{~min}$ in $300 \mu \mathrm{l}$ cell culture lysis reagent (Promega). After removal of cellular debris by centrifugation at $10000 \boldsymbol{g}$ for $15 \mathrm{~s}$, luciferase activity was measured in $5 \mu \mathrm{l}$ supernatant after addition of $30 \mu \mathrm{l}$ luciferase assay reagent (Promega). Peak light emission was recorded on a TD-20/20 Luminometer (Turner Designs, Sunnyvale, CA, USA). $\beta$-Galactosidase activity of 30-100 $\mu$ l clear lysate was measured in a $1-\mathrm{ml}$ reaction containing $0.3 \mathrm{mM} \quad \mathrm{MgCl}_{2}, 13.5 \mathrm{mM}$ $\beta$-mercaptoethanol, $\quad 0.9 \mathrm{mM} \quad$ ONPG (2-nitrophenyl- $\beta$-D-galactopyranoside) and $0 \cdot 1 \mathrm{M}$ sodium phosphate, pH 7.5. After incubation at $37^{\circ} \mathrm{C}$ (usually $20 \mathrm{~min}$ to $1 \mathrm{~h}$ ), the reaction was stopped by addition of $0.5 \mathrm{ml} 0.5 \mathrm{M} \mathrm{Na} \mathrm{NaO}_{3}$, and the intensity of the yellow colour was determined by its optical density at $420 \mathrm{~nm}$. The expression plasmids encoding rat HNF-4 $\alpha$ (pcDNA3.HNF4 $\alpha$; BartoovShifman et al. 2002), mouse PGC-1 $\alpha$ (pSV2-PGC1; Puigserver et al. 1998) and human insulin receptor B (InsRB; Yoshimata et al. 1988) were kindly provided by Drs M.D. Walker (Weizmann Institute of Science, Israel), B.M. Spiegelman (Harvard Medical School, USA), and J. Whittaker (Case Western Reserve University, USA) respectively.

\section{Northern blotting analysis}

Total RNA was isolated from liver samples of S. aurata with the Total Quick RNA Cells \& Tissues kit (Talent, Trieste, Italy). An amount of $20 \mu \mathrm{g}$ of total RNA was denatured and then loaded onto a $1 \%$ agarose gel containing $4 \cdot 75 \%$ formaldehyde. Electrophoresis was performed in denaturing conditions for $5 \mathrm{~h}$ at $35 \mathrm{~V}$; RNA was then transferred overnight to Nytran membranes (Schleicher \& Schuell $)$ in $5 \times \mathrm{SSC}(1 \times \mathrm{SSC}=150 \mathrm{mM}$ $\mathrm{NaCl}$ and $15 \mathrm{mM}$ sodium citrate, $\mathrm{pH} 7 \cdot 5)$. RNA was cross-linked to the membranes by UV irradiation for 3 min. A G6Pase homologous probe was labelled by incorporation of digoxigenin-11dUTP during PGR with primer pairs Fl (5'GTCGTGGGAGACTGGG TCAAC-3')/F2R (5'CGACTTCTGGGCTTTC TCAA-3'), which correspond to nucleotides 223-243 and 759-740 respectively in the $S$. aurata G6Pase cDNA (Metón et al. 2004). Prehybridisations of the membranes proceeded for $2 \mathrm{~h}$ at $50{ }^{\circ} \mathrm{C}$ in $7 \% \operatorname{SDS}(\mathrm{w} / \mathrm{v}), 50 \%$ formamide, $5 \times \mathrm{SSC}$, $2 \%$ blocking reagent (Roche), $0 \cdot 1 \% \mathcal{N}$-laurylsarcosine $(\mathrm{w} / \mathrm{v})$ and $50 \mathrm{mM}$ sodium phosphate, $\mathrm{pH} 7 \cdot 0$. The probes were added and hybridisation was performed overnight at $50{ }^{\circ} \mathrm{C}$. Membranes were then washed twice for $15 \mathrm{~min}$ at room temperature in $2 \times \mathrm{SSC}, 0 \cdot 1 \% \mathrm{SDS}$ and twice for $15 \mathrm{~min}$ at $68{ }^{\circ} \mathrm{C}$ in $0.2 \times \mathrm{SSC}$ and $0 \cdot 1 \%$ SDS. For normalisation, hybridisation of membranes with $\beta$-actin was carried out. Labelled probes were immunodetected with antidigoxigenin conjugated to alkaline phosphatase (Roche) and CDP-Star (Roche) as chemiluminescent substrate. Membranes were finally exposed to Hyperfilm ECL (Amersham). Autoradiograms of Northern blots were quantified by scanning densitometry.

\section{Hepatocyte isolation and semiquantitative RT-PCR}

S. aurata hepatocytes were isolated by collagenase digestion. Minced tissue was incubated in L15 medium containing $0.5 \mathrm{mg} / \mathrm{ml}$ collagenase (Sigma) for $30 \mathrm{~min}$ at $20^{\circ} \mathrm{C}$. The cell suspension was centrifuged at $100 \mathrm{~g}$ for $3 \mathrm{~min}$, and the supernatant was discarded. Cells were then washed three times with PBS and suspended in DMEM medium supplemented with $10 \%$ fetal bovine serum, 100 $\mathrm{IU} / \mathrm{ml}$ penicillin and $100 \mu \mathrm{g} / \mathrm{ml}$ streptomycin for $30 \mathrm{~min}$ at $20^{\circ} \mathrm{C}$. For analysis of the effect of glucose and insulin on $G 6 p c$ expresssion, the cells were incubated for $4 \mathrm{~h}$ at $20^{\circ} \mathrm{C}$ in serum-free DMEM medium supplemented with $100 \mathrm{IU} / \mathrm{ml}$ penicillin and $100 \mu \mathrm{g} / \mathrm{ml}$ streptomycin, and with or without $5 \mathrm{mM}$ glucose or $10 \mathrm{nM}$ recombinant human insulin (Sigma). Cell viability, estimated by Trypan blue exclusion, was $>95 \%$. Total RNA from cells was obtained with the Total Quick RNA Cells \& Tissues kit (Talent). cDNA templates for PCR amplification were synthesised from $1 \mu \mathrm{g}$ total RNA with MMLV-RT (BRL Life Technologies, Carlsbad, CA, USA) for $60 \mathrm{~min}$ at $37^{\circ} \mathrm{C}$ in the presence of random hexamer primers. The RT reaction products were subjected to PCR amplification. F6 (5'-CTG TGCTTGACGTGGCTGGG$3^{\prime}$ ) and F8R (5'-CG GCTGGTGACATCAGAGT GG-3') were used as primers to amplify a $673 \mathrm{bp}$ fragment of G6Pase (Metón et al. 2004). S. aurata $\beta$-actin was used as an internal control for quality and quantity of RNA. Each PCR reaction contained cDNA template, PCR buffer, $0.2 \mathrm{mM}$ 
A

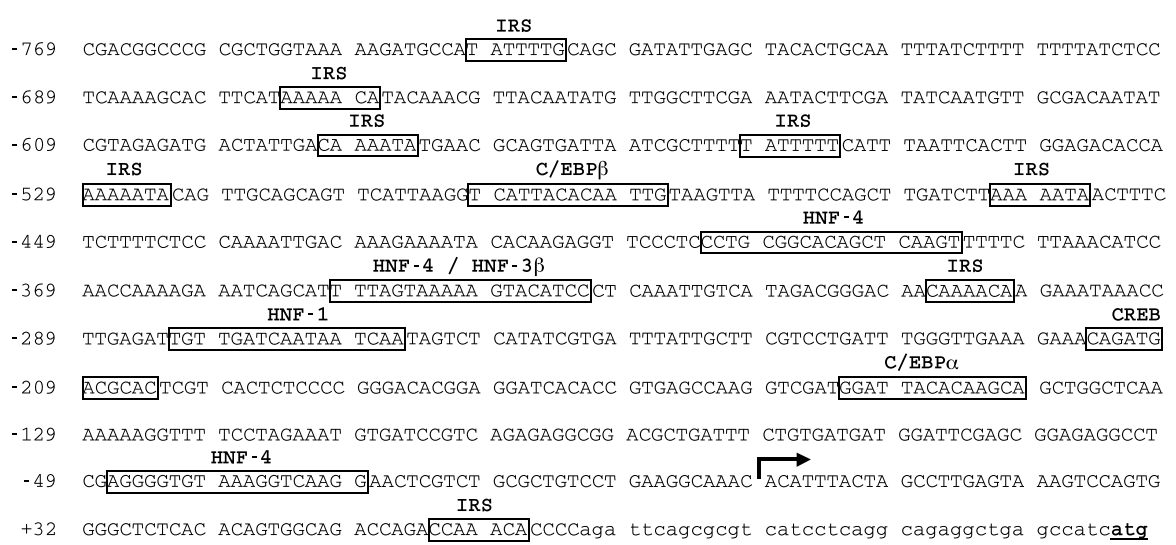

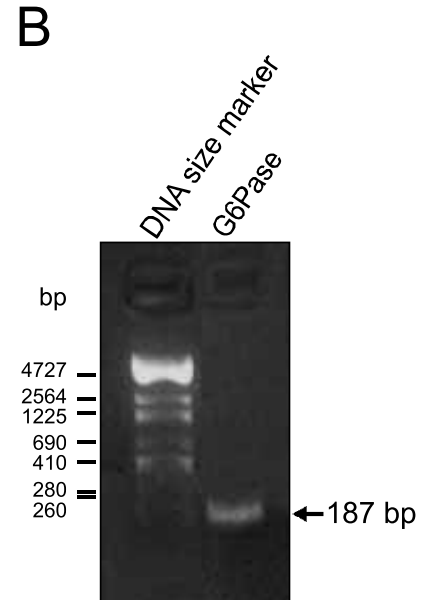

Figure 1 Sequence analysis of the $5^{\prime}$-flanking region of the $S$. aurata G6pc and mapping of the transcription initiation site of G6Pase mRNA. (A)The upstream sequences isolated by chromosome walking are shown in capitals. An arrow indicates the transcription start site. The translation start codon ATG is in boldface and underlined. Putative binding sites for transcription factors and IRS motifs are boxed. (B) Resolution of SMART RACE PCR products on a $2 \%$ agarose gel is shown. The assay, performed with $1 \mu \mathrm{g}$ hepatic poly $\mathrm{A}^{+} \mathrm{RNA}$, produced a $187 \mathrm{bp}$ band that was purified, ligated into pGEM T Easy and sequenced.

dNTP, $250 \mu \mathrm{M}$ of each primer and $1 \mathrm{U}$ Taq DNA polymerase (Biotools). After initial denaturation at $94{ }^{\circ} \mathrm{C}$ for $2 \mathrm{~min}$, a number of cycles $(20-30)$ at $94^{\circ} \mathrm{C}$ for $30 \mathrm{~s}, 60{ }^{\circ} \mathrm{C}$ for $30 \mathrm{~s}$ and $72{ }^{\circ} \mathrm{C}$ for $2 \mathrm{~min}$ were performed to verify that the PCR products amplify linearly and to determine the optimal number of cycles allowing their detection without saturation of the signal. Aliquots of each reaction were electrophoresed on a $2 \%$ agarose gel, and band intensities were compared by imaging of ethidium bromide staining.

\section{Statistics}

Data were analysed by one-factor analysis of variance by a computer program (StatView, SAS Institute, Cary, NG, USA). Differences were determined by Fisher's PLSD multiple range test, with significance level at $P<0 \cdot 01$.

\section{Results}

\section{Cloning of the $5^{\prime}$-flanking region of the $S$. aurata G6pc gene}

An 850 bp fragment upstream of the translation start codon of G6pc was isolated by chromosome walking on $S$. aurata genomic DNA, using oligonucleotides designed from the hepatic G6Pase catalytic subunit cDNA previously cloned from this species
(Metón et al. 2004) (Fig. 1A). The putative transcription initiation site of G6Pase mRNA was determined by the SMART RACE PCR approach (Zhu et al. 2001). A single fragment was obtained and cloned into pGEM T Easy. Upon sequencing, this fragment exhibited complete homology to the 39 bases in the $5^{\prime}$ untranslated region (UTR) of the previously cloned $S$. aurata G6Pase cDNA. Analysis of two independent clones indicated that $S$. aurata G6Pase mRNA initiates 106 nucleotides upstream of the translation start codon (Fig. 1B). Sequence

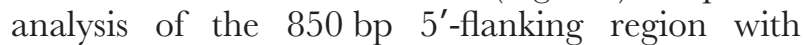
MOTIF-TRANSFAC 6•0 (Heinemeyer et al. 1999) revealed lack of basal elements such as a TATA box or a CAAT box, and presence of several putative transcription factor binding sites in the proximal region of the promoter. Among the potential transcription factors were sites for CREB, HNF-1, HNF-3 $\beta$ and HNF-4 $\alpha$, all implicated in the transcriptional activation of $G 6 p c$ promoter in mammals (Fig. 1A). The nucleotide sequence reported in this paper was submitted to the DDBJ/ EMBL/GeneBank databases under accession no. AY344583.

\section{Identification of a functional S. aurata G6pc promoter}

To determine whether the genomic DNA flanking exon 1 contains a functional promoter, the $850 \mathrm{bp}$ 

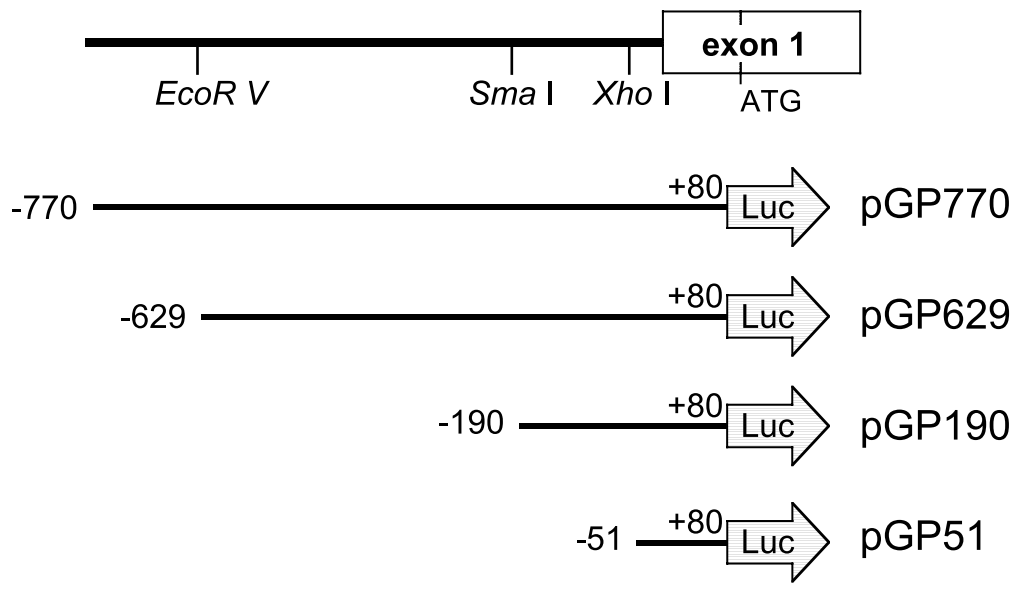

pGL3-Basic

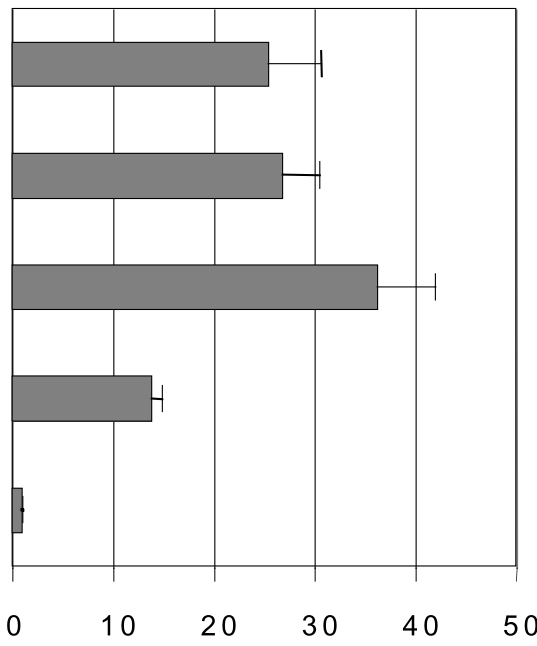

Relative luciferase activity

Figure 2 Deletion analysis and promoter activity of the $5^{\prime}$-flanking region of $S$. aurata G6pc in HepG2 cells. The top left part represents the genomic organisation of the $5^{\prime}$-flanking region of $S$. aurata G6pc. Relevant restriction sites and exon 1, depicted as a white box, are indicated. Nucleotide numbering starts with +1 , corresponding to the transcription initiation site. The $S$. aurata G6pc promoter having varying $5^{\prime}$ ends and an identical $3^{\prime}$ end $(+80)$ was fused to the luciferase reporter gene in pGL3-Basic vector. The constructs were transfected in HepG2 cells along with CMV- $\beta$ ( IacZ) to normalise for transfection efficiency. Luciferase activity is expressed as a fold increase over promoterless reporter plasmid pGL3-Basic. Results presented are the mean \pm S.D. from at least three independent experiments performed in duplicate.

fragment isolated by chromosome walking was subcloned in the promoterless plasmid pGL3-Basic, upstream of the luciferase reporter gene. The recombinant plasmid pGP770 $(-770 /+80)$ was transiently cotransfected into HepG2 cells together with a lacZ-containing plasmid, as internal control for transfection efficiency. The cell lysate was assayed for luciferase and $\beta$-galactosidase activity $20 \mathrm{~h}$ after transfection. This construct exhibited more than 25-fold increase in luciferase activity relative to the promoterless vector, pGL3-Basic (Fig. 2). This result indicated that the region comprised within 770 nucleotides upstream of the transcription start site of $S$. aurata $G 6 p c$ contains a functional promoter.

\section{Transcriptional activity of G6pc promoter deletions}

To examine the functional regions of the promoter involved in modulation of basal G6pc expression in
S. aurata, sequential 5'-deletion analysis of the promoter fragment was carried out. To this end, deletion fragments, with $5^{\prime}$ ends ranging from -770 to -51 and $3^{\prime}$ ends at +80 , were fused to the luciferase reporter gene and transfected into HepG2 cells. After $20 \mathrm{~h}$, luciferase activity was measured in crude cell lysate. The longest 5' construct (pGP770; -770 to +80 ) yielded a 25 -fold increase in luciferase activity relative to pGL3-Basic (Fig. 2). Similar results were obtained with pGP629 $(-629$ to +80$)$. Upon further deletion of 580 bases (pGP190; -190 to +80 ), a noticeable but non-significant increase with respect to pGP770 and pGP629 was observed. Thus, the pGP190 construct exhibited the highest increase in luciferase activity, 35-fold. These results indicate that motifs located between -770 and -190 do not play an essential role in the $G 6 p c$ promoter basal activity in HepG2 cells. The lower promoter activity was observed with the construct containing the promoter region spanning -51 to +80 (pGP51), 
which exhibited a 13-fold increase compared with the promoterless pGL3-Basic and a 64\% reduction in luciferase activity compared with pGP190. Therefore, positive cis-elements may be found between nucleotide positions -190 and -51 , as well as in the region comprised within 51 nucleotides upstream of the transcription start site.

\section{Regulation of hepatic glucose-6-phosphatase expression by glucose and insulin in vivo and in isolated hepatocytes}

To investigate in vivo effects of glucose and insulin on $G 6 p c$ expression in the liver of $S$. aurata, four groups of fish were injected with glucose, insulin, glucose plus insulin, or saline (vehicle). Hepatic G6Pase mRNA levels were assessed $6 \mathrm{~h}$ after the treatment, by Northern blotting analysis. Administration of glucose, insulin or glucose plus insulin reduced G6Pase mRNA to $50 \%, 40 \%$ and $28 \%$ respectively, of control (saline) (Fig. 3A). Similar results were observed in $G 6 p c$ expression in isolated hepatocytes by semiquantitative RT-PCR after treatment for $4 \mathrm{~h}$ with insulin and glucose plus insulin. No reduction of G6Pase mRNA levels was observed in hepatocytes incubated in the presence of glucose alone (Fig. 3B). The effect of insulin and glucose administration on serum glucose levels was also determined. Compared with control fish $(146.51 \pm 6.08 \mathrm{mg} / \mathrm{dl}$, mean \pm S.D., $n=5)$, insulin treatment significantly reduced glycaemia, to $54 \%$ $(79 \cdot 44 \pm 14 \cdot 85 \mathrm{mg} / \mathrm{dl}, n=5)$, whereas both glucose and glucose plus insulin caused a 12-15-fold increase $(1682 \cdot 30 \pm 684 \cdot 04 \mathrm{mg} / \mathrm{dl}, \quad n=6 ; \quad$ and $2276 \cdot 87 \pm 585 \cdot 39 \mathrm{mg} / \mathrm{dl}, n=6$, respectively).

\section{Regulation of G6pc promoter activity by glucose and insulin in HepG2 cells}

In view of the effect of glucose and insulin on hepatic G6Pase mRNA levels in vivo and on isolated hepatocytes, and to study further the molecular mechanism by which glucose and insulin regulate $G 6 p c$ expression in $S$. aurata, HepG2 cells transiently transfected with G6pc promoter fragments fused to the luciferase reporter gene were incubated in the presence or absence of glucose and insulin. Addition of up to $25 \mathrm{mM}$ glucose to the culture medium caused a marked, dose-dependent increase in G6pc promoter activity (Fig. 4A). Addition of insulin in the absence of glucose did not affect luciferase activity with the longer $5^{\prime}$ construct (pGP770) or the shorter $5^{\prime}$ construct (pGP51). However, in the presence of $5 \mathrm{mM}$ glucose, insulin repressed promoter activity of both pGP770 and pGP51 constructs (Fig. 4B). Thus, insulin overrode the effect of glucose on $G 6 p c$ promoter activity in $S$. aurata, and the putative cis-element for insulin action may be located downstream of position -51 relative to the transcription start site.

\section{Synergistic activation of G6pc promoter by HNF-4 $\alpha$ and PGC-1 $\alpha$}

Efficient promoter activation often requires the synergistic effect of transcription factors and coactivator proteins. At present, the mechanism by which insulin downregulates the expression of gluconeogenic genes remains unclear. Recently, Puigserver et al. (2003) suggested that insulin suppresses gluconeogenesis stimulated by PGC- $1 \alpha$ through disruption of PGC- $1 \alpha-$ Foxol interaction. We tested whether simultaneous overexpression of PGG- $1 \alpha$ and HNF- $4 \alpha$ resulted in G6pc promoter activation to levels higher than with one transcription factor alone. The pGP770 construct was activated about fivefold by PGC- $1 \alpha$ alone, whereas HNF- $4 \alpha$ caused fourfold activation. The combination of HNF-4 $\alpha$ and PGC-1 $\alpha$ resulted in 20-fold activation of the G6pc promoter (Fig. 5). In order to identify the region responsible for the synergistic effect of HNF-4 $\alpha$ and PGC- $1 \alpha$, the same experiment was carried out in the $5^{\prime}$ deletion constructs pGP629, pGP190 and pGP51. HepG2 cells cotransfected with pGP629, pGP190 or pGP51 and expression plasmids for HNF-4 $\alpha$ and PGC-1 $\alpha$ lacked the synergistic effect (Fig. 5), suggesting that the region located between positions -770 and -629 relative to the transcription start site is required for this effect.

\section{Discussion}

Disturbed regulation of $G 6 p c$ expression by insulin contributes to increased hepatic glucose production and to NIDDM in mammals. The advent of carnivorous fish as a glucose-intolerant system for the study of non-insulin-dependent diabetes (Wilson 1994, Caseras et al. 2000, Moon 2001) led us to isolate and characterise modulation of the promoter region of $G 6 p c$ from $S$. aurata by glucose 

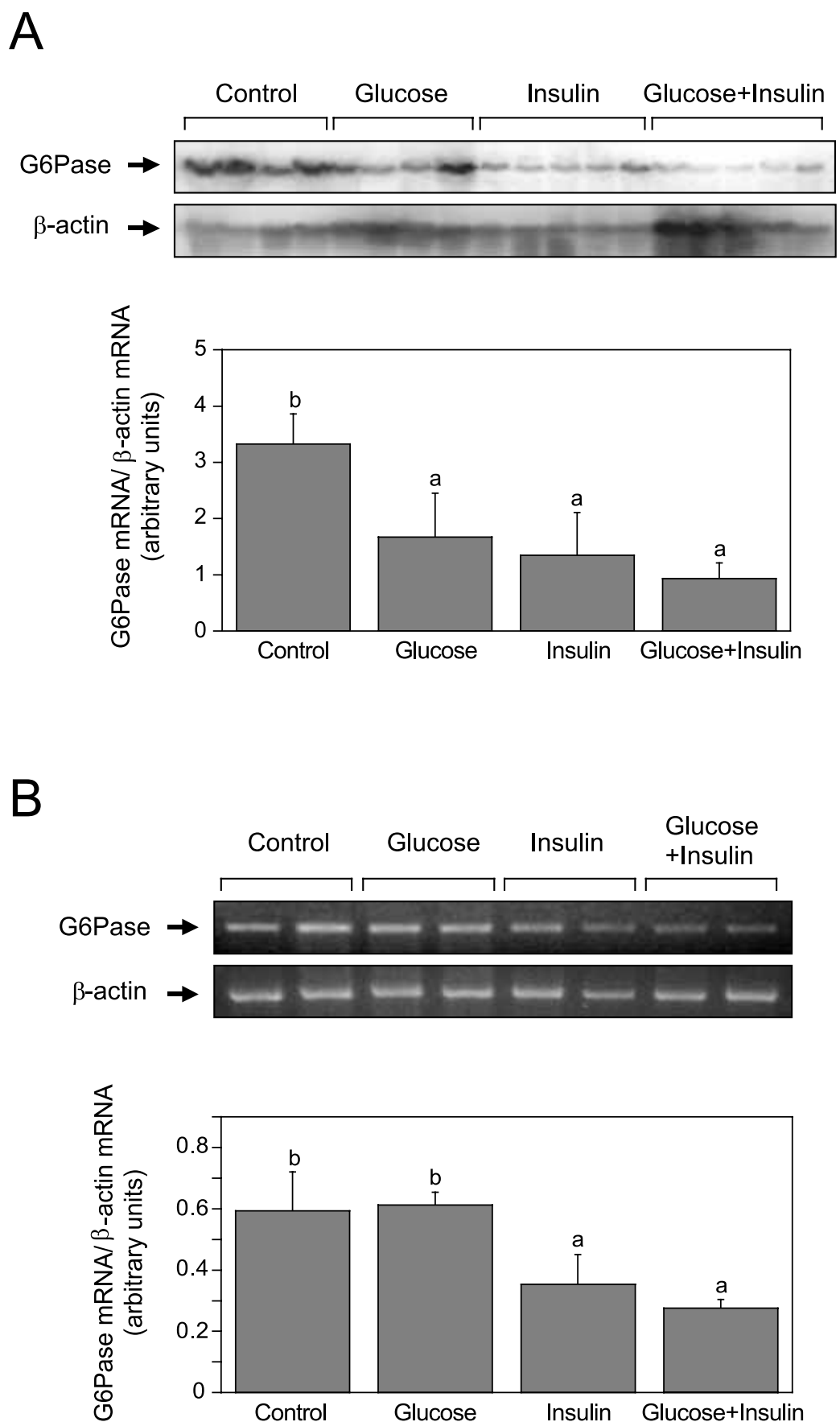

Figure 3 Effect of glucose and insulin on hepatic G6Pase mRNA in vivo and in isolated hepatocytes from S. aurata. (A) Northern blot and densitometric analysis of G6Pase mRNA levels in liver of fish $6 \mathrm{~h}$ after treatment with saline (control), glucose (2 g/kg fish), insulin (10 units/kg fish) or glucose (2 g/kg fish) plus insulin (10 units $/ \mathrm{kg}$ fish). An amount of $20 \mu \mathrm{g}$ total RNA was loaded in each lane. G6Pase mRNA levels are expressed as mean \pm S.D. of four or five fish. (B) Semiquantitative RT-PCR and densitometric analysis of G6Pase mRNA levels in isolated hepatocytes $4 \mathrm{~h}$ after no treatment (control) or treatment with glucose $(5 \mathrm{mM})$, insulin $(10 \mathrm{nM})$ or glucose $(5 \mathrm{mM})$ plus insulin $(10 \mathrm{nM})$. G6Pase mRNA levels are expressed as mean \pm S.D. of two independent duplicate experiments. Different letters denote significant differences among treatments $(P<0.01)$. 
A

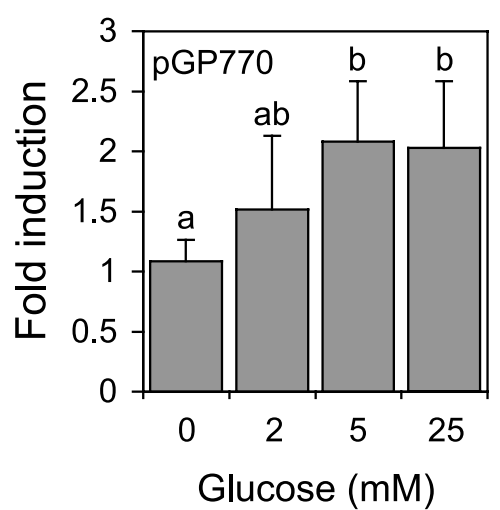

B

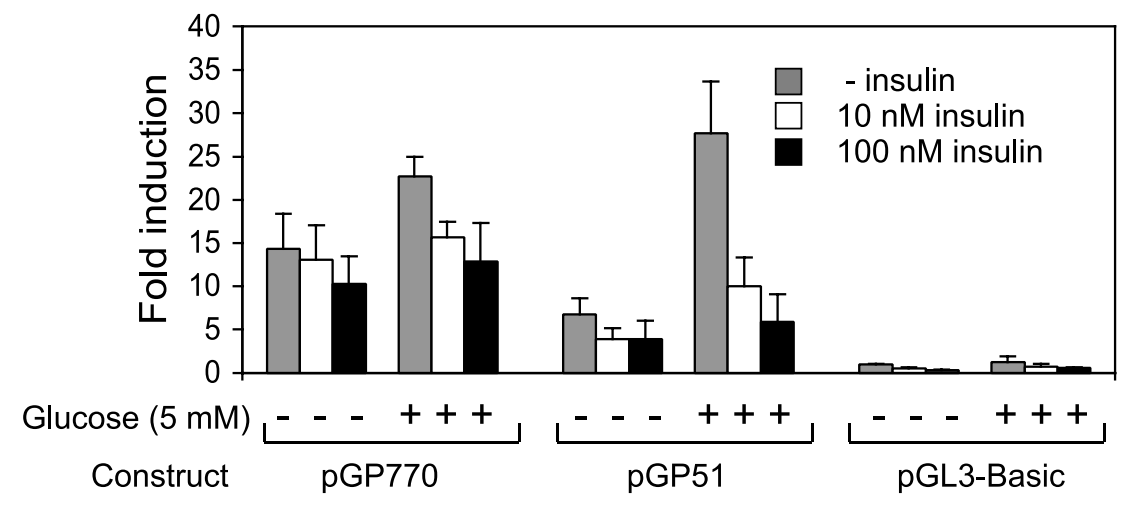

Figure 4 Effect of glucose and insulin on the activity of $S$. aurata G6pc promoter in HepG2 cells. (A) HepG2 cells transiently transfected with the pGP770 promoter construct were cultured in the presence $(2,5$ and $25 \mathrm{mM})$ or absence of glucose in the medium, and luciferase activity was measured $16 \mathrm{~h}$ later. The promoter activity of pGP770 in the absence of glucose was set at 1 . Different letters indicate significant differences $(P<0.01)$.

(B) HepG2 cells were transiently transfected with pGL3-Basic or the promoter constructs pGP770 or pGP51, and $800 \mathrm{ng}$ expression vector encoding human insulin receptor B. After transfection, the cells were cultured in the presence $(5 \mathrm{mM})$ or absence of glucose, and with 10 or $100 \mathrm{nM}$ insulin or without human insulin in serum-free medium. The promoter activity of pGL3-Basic in the absence of glucose and insulin was set at 1 . Variations in transfection efficiencies were corrected with CMV- $\beta$ (lacZ) as an internal control. The data represent the mean \pm S.D. values of three independent duplicate experiments.

and insulin. Understanding the transcriptional regulation of $G 6 p c$ in carnivorous fish may explain why these animals are glucose intolerant. We previously reported that long-term starvation and energy restriction increase hepatic $G 6 p c$ expression at mRNA level in S. aurata (Caseras et al. 2002). Consistent with strong dependence upon G6pc expression of hepatic glucose cycling in mammals

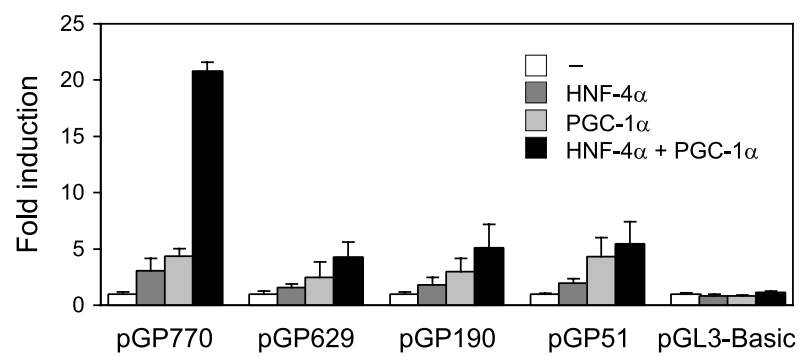

Figure 5 Effect of HNF- $4 \alpha$ and PGC- $1 \alpha$ on the activity of $S$. aurata G6pc promoter in HepG2 cells. The cells were transiently transfected with pGL3-Basic or the promoter constructs pGP770, pGP629, pGP190 or pGP51, either with or without $400 \mathrm{ng}$ expression plasmids encoding HNF- $4 \alpha$ or PGC- $1 \alpha$. The promoter activity of reporter constructs alone was set at 1 . Variations in transfection efficiencies were corrected for using CMV- $\beta$ (lacZ) as an internal control. The data represent the mean \pm S.D. values of two independent duplicate experiments.
(Nordlie et al. 1999, Pagliassotti et al. 2003), postprandial short-term modulation of G6Pase mRNA in the liver of regularly fed $S$. aurata occurs, with minimal mRNA levels $4-15 \mathrm{~h}$ after food intake (Caseras et al. 2002). In the present study, we have isolated the 5 '-flanking region of the $S$. aurata $G 6 p c$ and analysed its promoter activity in HepG2 cells by transient transfection. This genomic fragment allowed us to assess transcriptional regulation of the piscine $G 6 p c$ promoter by glucose and insulin, and to identify trans-regulatory factors.

The promoter region of $S$. aurata $G 6 p c$ was cloned by chromosome walking. Mapping of the transcriptional start indicated the presence of a start site located $106 \mathrm{bp}$ upstream of the translation start codon. Our localisation of the transcription start site predicts an $1815 \mathrm{bp}$ mRNA, which is consistent with the $1.8 \mathrm{~kb}$ transcript identified by Northern blotting (Metón et al. 2004).

The functionality of the putative promoter region of fish $G 6 p c$ was tested by transient transfection of HepG2 cells with fusion constructs of the $850 \mathrm{bp}$ isolated by chromosome walking and sequential $5^{\prime}$ deletions of this fragment to the luciferase gene. The longest construct (pGP770) exhibited 25-fold higher luciferase activity than the promoterless pGL3-Basic. Deletions of the promoter region 
between -770 and -190 did not significantly affect the promoter activity as compared with the pGP770 construct. Therefore, it can be inferred that this region is not essential for promoter basal activity. Deletion between -190 and -51 resulted in a significant decrease in the promoter activity. The shorter construct -51 to +80 (pGP51) conferred moderate promoter activity. These data suggest the presence of positive regulatory element(s) within $190 \mathrm{bp}$ upstream of the transcription start site, and indicate that this region is a core functional promoter for basal transcriptional activation of $G 6 p c$.

In rats, starvation and hormones that increase cAMP stimulate $G 6 p c$ expression, whereas refeeding and insulin administration decrease it (Argaud et al. 1996, Minassian et al. 1999). Insulin inhibits basal $G 6 p c$ expression as well as $G 6 p c$ stimulation by glucose, glucocorticoids, cAMP and fatty acids. Studies in vivo and in vitro have shown that glucose stimulates $G 6 p c$ expression in rats. However, the induction of $G 6 p c$ by glucose is paradoxical and has been linked to a balancing effect with that of insulin to avoid complete depletion of the enzyme during meal absorption, to control the hepatic glycogen storage and to prepare the transition to fasting periods (Argaud et al. 1997, Chatelain et al. 1998, Massillon 2001).

In the present study, repression of $G 6 p c$ occurred in insulin-treated fish and isolated hepatocytes. In contrast to glucose-dependent activation of $G 6 p c$ expression in rats, G6Pase mRNA levels decreased in $S$. aurata after glucose administration. Interestingly, glucose did not modulate $G 6 p c$ expression in isolated hepatocytes, suggesting that glucosedependent repression in vivo may result from a prevailing effect of insulin in a physiological state that leads to increased insulin levels. Treatment with glucose plus insulin resulted in a marked reduction of G6Pase mRNA both in vivo and in isolated hepatocytes. These findings argue for an in vivo repression of $G 6 p c$ in the liver of $S$. aurata caused by a hyperglycaemic state following food intake. This agrees with suppression of hepatic glucose production by hyperinsulinaemia and hyperglycaemia through inhibition of G6Pase in rats (Guignot \& Mithieux 1999), and with the postprandial rise in blood glucose levels followed by a decrease of hepatic G6pc expression previously observed in regularly fed fish (Caseras et al. 2002). The lack of stimulatory effect of glucose on fish G6pc in vivo is consistent with previous results indicating that increasing carbohydrate dietary content does not affect hepatic G6Pase mRNA levels in S. aurata (Caseras et al. 2002). Likewise, Hornbuckle et al. (2001) did not observe a stimulatory effect of glucose on G6Pase mRNA in conscious dogs, whereas insulin had an inhibitory effect. Thus, control of $G 6 p c$ expression in carnivorous animals such as $S$. aurata and dogs followed a similar mechanism, which in turn differs from that in rats (omnivore). In HepG2 cells transfected with $770 \mathrm{bp}$ of the $S$. aurata G6pc promoter region, absence of insulin in the culture medium allowed a positive regulatory effect of glucose on the transcriptional activity of the fish G6pc promoter. Since glucose administration leads to increased insulin release in vivo, the observation that glucose decreased G6Pase mRNA levels in the liver of $S$. aurata may result from a prevailing inhibitory effect of insulin over the effect of glucose on G6pc promoter. The possible contribution of glucose-derived metabolites and other hormones to suppression of $G 6 p c$ transcription in fish cannot be excluded.

In contrast to the strong inhibitory effect of insulin on rat $G 6 p c$ promoter activity in $\mathrm{H} 4$ IIE hepatoma cells in the absence of glucose (Chen et al. 2000), insulin hardly affected the transcriptional activity of $S$. aurata $G 6 p c$ promoter in HepG2 cells under a no-glucose condition. However, a repressing effect of insulin was observed in the presence of glucose, a situation that is probably closer to the postprandial state in the piscine liver. Hence, as in mammals, insulin overrode glucosemediated activation of $S$. aurata $G 6 p c$ promoter. Since the ability of insulin to repress hepatic glucose production is reduced in NIDDM, the fact that insulin had no significant effect on the activity of $S$. aurata $G 6 p c$ promoter under low-glucose conditions suggests that glucose availability determines insulin-dependent repression of piscine $G 6 p c$, and thus may contribute to insulin resistance in carnivorous fish.

Recent studies illustrate the role of the coactivator PGC- $1 \alpha$ in the transcriptional activation of mammalian gluconeogenic genes, such as G6pc and phosphoenolpyruvate carboxykinase 1 (Pckl). PGG-1 $\alpha$ has been shown to mediate induction of mouse G6pc by HNF-4a (Boustead et al. 2003, Rhee et al. 2003). Puigserver et al. (2003) showed that coactivation by PGG-1 $\alpha$ is critical for Foxoldependent transcriptional activation of the $G 6 p c$ 
and $P c k 1$ promoters in mice, leading the authors to propose a model in which gluconeogenic gene expression is inhibited by insulin via a PKBdependent disruption of the complex formed with the coactivator protein PGC-1 $\alpha$ and Foxol. Indeed, $P g c 1$ promoter activity is induced by coexpression of Foxol via the IRS within the $P g c 1$ promoter in HepG2 cells, and coexpression of PKB was found to mimic the inhibitory effect of insulin on $P g c 1$ promoter activity (Daitoku et al. 2003). In addition, glucagon may stimulate $G 6 p c$ expression via PGC-1 $\alpha$. The expression of Pgcl is induced by glucagon via cAMP, leading to increased $G 6 p c$ expression, probably by the interaction of PGC- $1 \alpha$ with HNF-4 $\alpha$ and the glucocorticoid receptor. In liver, fasting markedly induces PGC- $1 \alpha$ expression (Lin et al. 2002), and overexpression of PGC-1 $\alpha$ in primary hepatocytes increases glucose production and the expression of G6pc and Pckl (Yoon et al. 2001). Furthermore, in several models of NIDDM that are associated with increased gluconeogenesis, Pgcl gene expression is also elevated (Hara et al. 2002, Yoon et al. 2003). On the other hand, heterozygous mutations in the HNF4a gene give rise to maturity onset diabetes of the young type 1 (Ryffel 2001). We investigated the effect of overexpression of HNF- $4 \alpha$ and PGC- $1 \alpha$ on G6pc promoter activity in HepG2 cells cotransfected with plasmids ranging from -770 to +80 relative to the transcription start site in the $S$. aurata $G 6 p c$ promoter and sequential $5^{\prime}$ deletions of this fragment. A synergistic effect was observed through cotransfection with both HNF- $4 \alpha$ and PGC- $1 \alpha$ and the longest promoter construct, suggesting that coactivation of HNF- $4 \alpha$ occurs in S. aurata. Loss of synergism was observed with the shorter constructs, indicating that the sequence between -770 and -629 in the $S$. aurata $G 6 p c$ promoter region is essential for this effect, presumably by binding of $\mathrm{HNF}-4 \alpha$ to this region. These findings suggest that the major role attributed to PGC- $1 \alpha$ in turning on the gluconeogenic programme in mammals may also occur in fish. Since the pGP51 construct was modestly activated by overexpression of PGC- $1 \alpha$, a second cis-element involved in PGG- $1 \alpha$ stimulation within the 51 bp upstream of the transcription start of the $S$. aurata $G 6 p c$ promoter cannot be ruled out. However, this putative site would be neither necessary nor sufficient for PGC- $1 \alpha$ coactivation of HNF-4 $\alpha$. The fact that insulin repressed the promoter activity of pGP51 construct excludes a model involving suppression of PGC- $1 \alpha$ coactivation of HNF-4 $\alpha$ in the piscine $G 6 p c$ promoter to explain insulin repression of $S$. aurata $G 6 p c$ under high-glucose conditions, as occurs with insulindependent disruption of the PGG- $1 \alpha-$ Foxol complex in mice (Puigserver et al. 2003). Further studies are needed to identify cis-elements involved in insulin repression of fish $G 6 p c$.

\section{Acknowledgements}

The authors wish to thank Drs M D Walker, B M Spiegelman and $\mathrm{J}$ Whittaker for providing the HNF-4 $\alpha$, PGC-1 $\alpha$ and insulin receptor B expression vectors respectively. This study was supported by grants from MCYT (Spain), BMC2000-0761 and BIO2003-01098. M Egea is the recipient of a fellowship from the University of Barcelona. We thank the Language Advisory Service of the University of Barcelona for correcting the English manuscript.

\section{References}

Argaud D, Zhang Q, Pan W, Maitra S, Pilkis SJ \& Lange AJ 1996 Regulation of rat liver glucose-6-phosphatase gene expression in different nutritional and hormonal states. Gene structure and 5'-flanking sequence. Diabetes 45 1563-1571.

Argaud D, Kirby TL, Newgard CB \& Lange AJ 1997 Stimulation of glucose-6-phosphatase gene expression by glucose and fructose-2,6-bisphosphate. Foumal of Biological Chemistry 272 12854-12861.

Baanante IV, García de Frutos P, Bonamusa L \& Fernández F 1991 Regulation of fish glycolysis-gluconeogenesis: role of fructose 2,6-P2 and PFK-2. Comparative Biochemistry and Physiology 100B $11-17$.

Bartoov-Shifman R, Hertz R, Wang H, Wollheim CB, Bar-Tana J \& Walker MD 2002 Activation of the insulin gene promoter through a direct effect of hepatocyte nuclear factor $4 \alpha$. Fournal of Biological Chemistry $27725914-25919$.

Boustead JN, Stadelmaier BT, Eeds AM, Wiebe PO, Svitek CA, Oeser JK \& O'Brien RM 2003 Hepatocyte nuclear factor- $4 \alpha$ mediates the stimulatory effect of peroxisome proliferator-activated receptor gamma co-activator-1 $\alpha$ (PGC-1 $\alpha)$ on

glucose-6-phosphatase catalytic subunit gene transcription in $\mathrm{H} 4$ IIE cells. Biochemical fournal 369 17-22.

Caseras A, Metón I, Fernandez F \& Baanante IV 2000 Glucokinase gene expression is nutritionally regulated in liver of gilthead sea bream (Sparus aurata). Biochimica et Biophysica Acta 1493 135-141.

Caseras A, Metón I, Vives C, Egea M, Fernández F \& Baanante IV 2002 Nutritional regulation of glucose-6-phosphatase gene expression in liver of the gilthead sea bream (Sparus aurata). British Fournal of Nutrition 88 607-614.

Chatelain F, Pegorier JP, Minassian C, Bruni N, Tarpin S, Girard J \& Mithieux G 1998 Development and regulation of glucose-6-phosphatase gene expression in rat liver, intestine, and kidney: in vivo and in vitro studies in cultured fetal hepatocytes. Diabetes 47 882-889. 
Chen R, Meseck M, McEvoy RC \& Woo SL 2000

Glucose-stimulated and self-limiting insulin production by glucose 6-phosphatase promoter driven insulin expression in hepatoma cells. Gene Therapy 7 1802-1809.

Christiansen DC \& Klungsøyr L 1987 Metabolic utilization of nutrients and the effects of insulin in fish. Comparative Biochemistry and Physiology 88B 701-711.

Clore JN, Stillman J \& Sugerman H 2000 Glucose-6-phosphatase flux in vitro is increased in NIDDM. Diabetes 49 969-974.

Clottes E, Middleditch C \& Burchell A 2002 Rat liver glucose-6-phosphatase system: light scattering and chemical characterization. Archives of Biochemistry and Biophysics 408 33-41.

Cowey CB \& Walton MJ 1989 Intermediary metabolism. In Fish Nutrition, pp 260-321. Ed JE Halver. San Diego, CA: Academic Press.

Daitoku H, Yamagata K, Matsuzaki H, Hatta M \& Fukamizu A 2003 Regulation of PGC-1 promoter activity by protein kinase B and the forkhead transcription factor FKHR. Diabetes 52 642-649.

Foster JD \& Nordlie RC 2002 The biochemistry and molecular biology of the glucose-6-phosphatase system. Experimental Biology and Medicine 227 601-608.

Gautier-Stein A, Domon-Dell C, Calon A, Bady I, Freund JN, Mithieux G \& Rajas F 2003 Differential regulation of the glucose-6-phosphatase TATA box by intestine-specific homeodomain proteins CDX1 and CDX2. Nucleic Acids Research 31 5238-5246.

Graham FL \& Van der Eb AJ 1973 A new technique for assay of infectivity of human adenovirus 5. DNA Virology 52 456-467.

Guignot L \& Mithieux G 1999 Mechanisms by which insulin, associated or not with glucose, may inhibit hepatic glucose production in the rat. American Fournal of Physiology $\mathbf{2 7 7}$ E984-E989.

Guionie O, Clottes E, Stafford K \& Burchell A 2003 Identification and characterisation of a new human glucose-6-phosphatase isoform. FEBS Letters $\mathbf{5 5 1}$ 159-164.

Hara K, Tobe K, Okada T, Kadowaki H, Akanuma Y, Ito C, Kimura S \& Kadowaki T 2002 A genetic variation in the PGC-1 gene could confer insulin resistance and susceptibility to type II diabetes. Diabetologia 45 740-743.

Heinemeyer T, Chen X, Karas H, Kel AE, Kel OV, Liebich I, Meinhardt T, Reuter I, Schacherer F \& Wingender E 1999 Expanding the TRANSFAC database towards an expert system of regulatory molecular mechanisms. Nucleic Acids Research $\mathbf{2 7}$ 318-322.

Herzig S, Long F, Jhala US, Hedrick S, Quinn R, Bauer A, Rudolph D, Schutz G, Yoon C, Puigserver P, et al. 2001 CREB regulates hepatic gluconeogenesis through the coactivator PGG-1. Nature 413 179-183.

Hornbuckle LA, Edgerton DS, Ayala JE, Svitek CA, Oeser JK, Neal DW, Cardin S, Cherrington AD \& O'Brien RM 2001 Selective tonic inhibition of G-6-Pase catalytic subunit, but not G-6-P transporter, gene expression by insulin in vivo. American fournal of Physiology 281 E713-E725.

Huang A, Chen Y, Wang X, Zhao S, Su N \& White DW 2004 Functional silencing of hepatic microsomal glucose-6-phosphatase gene expression in vivo by adenovirus-mediated delivery of short hairpin RNA. FEBS Letters 558 69-73.

Lin B, Morris DW \& Chou JY 1997 The role of HNF1 $\alpha$, HNF3 $\gamma$, and cyclic AMP in glucose-6-phosphatase gene activation. Biochemistry 36 14096-14106.

Lin J, Puigserver P, Donovan J, Tarr P \& Spiegelman BM 2002 Peroxisome proliferator-activated receptor gamma coactivator $1 \beta$ (PGC-1 $\beta$ ), a novel PGC-1-related transcription coactivator associated with host cell factor. Fournal of Biological Chemistry 277 $1645-1648$.

Massillon D 2001 Regulation of glucose-6-phosphatase gene by glucose occurs by transcriptional and post-transcriptional mechanisms. Fournal of Biological Chemistry 276 4055-4062.
Massillon D, Barzilai N, Chen W, Hu M \& Rossetti L 1996 Glucose regulates in vivo glucose-6-phosphatase gene expression in the liver of diabetic rats. Fournal of Biological Chemistry 271 9871-9874.

Massillon D, Chen W, Barzilai N, Prus-Wertheimer D, Hawkins M, Liu R, Taub R \& Rossetti L 1998 Carbon flux via the pentose phosphate pathway regulates the hepatic expression of the glucose-6-phosphatase and phosphoenolpyruvate carboxykinase genes in conscious rats. Fournal of Biological Chemistry 273 228-234.

Massillon D, Arinze IJ, Xu C \& Bone F 2003 Regulation of glucose-6-phosphatase gene expression in cultured hepatocytes and H4 IIE cells by short-chain fatty acids: role of hepatic nuclear factor-4a. Fournal of Biological Chemistry $27840694-40701$.

Metón I, Egea M \& Baanante IV 2003 New insights into the regulation of hepatic glucose metabolism in fish. In Recent Research Developments in Biochemistry, vol 4 (1), pp 125-149. Ed SG Pandalai. Kerala, India: Research Signpost.

Metón I, Caseras A, Fernández F \& Baanante IV 2004 Molecular cloning of hepatic glucose-6-phosphatase catalytic subunit from gilthead sea bream (Sparus aurata): response of its mRNA levels and glucokinase expression to refeeding and diet composition. Comparative Biochemistry and Physiology B 138B 145-153.

Minassian C, Montano S \& Mithieux G 1999 Regulatory role of glucose-6 phosphatase in the repletion of liver glycogen during refeeding in fasted rats. Biochimica et Biophysica Acta 1452 172-178.

Moon TW 2001 Glucose intolerance in teleost fish: fact or fiction? Comparative Biochemistry and Physiology 129B 243-249.

Nordlie RC, Foster JD \& Lange AJ 1999 Regulation of glucose production by the liver. Annual Review of Nutrition 19 379-406.

Pagliassotti MJ, Wei Y \& Bizeau ME 2003 Glucose-6-phosphatase activity is not suppressed but the mRNA level is increased by a sucrose-enriched meal in rats. Fournal of Nutrition 133 32-37.

Puigserver P, Wuu Z, Park CW, Graves R, Wright M \& Spiegelman BM 1998 A cold-inducible coactivator of nuclear receptors linked to adaptive thermogenesis. Cell $\mathbf{9 2}$ 829-839.

Puigserver P, Rhee J, Donovan J, Walkey CJ, Yoon JC, Oriente F, Kitamura Y, Altomonte J, Dong H, Accili D, et al. 2003 Insulin-regulated hepatic gluconeogenesis through FOXO1-PGG- $1 \alpha$ interaction. Nature 423 550-555.

Rhee J, Inoue Y, Yoon JC, Puigserver P, Fan M, Gonzalez FJ \& Spiegelman BM 2003 Regulation of hepatic fasting response by PPAR $\gamma$ coactivator- $1 \alpha$ (PGC-1): requirement for hepatocyte nuclear factor $4 \alpha$ in gluconeogenesis. PNAS $1004012-4017$.

Ryffel GU 2001 Mutations in the human genes encoding the transcription factors of the hepatocyte nuclear factor (HNF) 1 and HNF4 families: functional and pathological consequences. Fournal of Molecular Endocrinology 27 11-29.

Schmoll D, Wasner C, Hinds CJ, Allan BB, Walther R \& Burchell A 1999 Identification of a cAMP response element within the glucose-6-phosphatase hydrolytic subunit gene promoter which is involved in the transcriptional regulation by cAMP and glucocorticoids in H4 IIE hepatoma cells. Biochemical foumal 338 $457-463$.

Streeper RS, Svitek CA, Chapman S, Greenbaum LE, Taub R \& O’Brien RM 1997 A multicomponent insulin response sequence mediates a strong repression of mouse glucose-6-phosphatase gene transcription by insulin. Fournal of Biological Chemistry 272 11698-11701.

Streeper RS, Eaton EM, Ebert DH, Chapman SC, Svitek CA \& O'Brien RM 1998 Hepatocyte nuclear factor-1 acts as an accessory factor to enhance the inhibitory action of insulin on mouse glucose-6-phosphatase gene transcription. PNAS 95 9208-9213.

Streeper RS, Svitek CA, Goldman JK \& O'Brien RM 2000 Differential role of hepatocyte nuclear factor-1 in the regulation of glucose-6-phosphatase catalytic subunit gene transcription by cAMP in liver- and kidney-derived cell lines. Fournal of Biological Chemistry 275 12108-12118. 
Vander Kooi BT, Streeper RS, Svitek CA, Oeser JK, Powell DR \& O'Brien RM 2003 The three insulin response sequences in the glucose-6-phosphatase catalytic subunit gene promoter are functionally distinct. Fournal of Biological Chemistry 278 11782-11793.

Van de Werve G, Lange AJ, Newgard C, Méchin M-C, Li Y \& Berteloot A 2000 New lessons in the regulation of glucose metabolism taught by the glucose-6-phosphatase system. European Fournal of Biochemistry 267 1533-1549.

Van Schaftingen E \& Gerin I 2002 The glucose-6-phosphatase system. Biochemical fournal 362 513-532.

Von Groote-Bidlingmaier F, Schmoll D, Orth HM, Joost HG, Becker W \& Barthel A 2003 DYRK1 is a co-activator of FKHR (FOXOla)-dependent glucose-6-phosphatase gene expression. Biochemical and Biophysical Research Communications 300 764-769.

Wasner C, Grempler R, Walther R \& Schmoll D 2001 Basal level glucose-6-phosphatase gene transcription requires binding sites for Sp family proteins within the gene promoter. Biochimica et Biophysica Acta 1521 126-129.

Wilson RP 1994 Utilization of dietary carbohydrate by fish. Aquaculture 124 67-80.

Yoon JG, Puigserver P, Chen G, Donovan J, Wu Z, Rhee J, Adelmant G, Stafford J, Kahn CR, Granner DK, et al. 2001
Control of hepatic gluconeogenesis through the transcriptional coactivator PGG-1. Nature 413 131-138.

Yoon JC, Xu G, Deeney JT, Yang SN, Rhee J, Puigserver P, Levens AR, Yang R, Zhang CY, Lowell BB, et al. 2003 Suppression of $\beta$ cell energy metabolism and insulin release by PGC- $1 \alpha$. Developmental Cell 5 73-83.

Yoshimasa Y, Seino S, Whittaker J, Kakehi T, Kosaki A, Kuzuya H, Imura H, Bell GI \& Steiner DF 1988 Insulin-resistant diabetes due to a point mutation that prevents insulin proreceptor processing. Science $\mathbf{2 4 0} 784-787$.

Zhu YY, Machleder EM, Chenchik A, Li R \& Siebert PD 2001 Reverse transcriptase template switching: a SMART approach for full-length cDNA library construction. Biotechniques $\mathbf{3 0}$ 892-897.

Received 19 July 2004 Accepted 9 August 2004 Made available online as an Accepted Preprint 15 September 2004 